\title{
Treatment of Triple-Negative Breast Cancer Cells with the Canady Cold Plasma Conversion System: Preliminary Results
}

\author{
Xiaoqian Cheng ${ }^{1,+}\left(\mathbb{C}\right.$, Warren Rowe ${ }^{1,+}+{ }^{1}$, Lawan Ly $^{1}$, Alexey Shashurin ${ }^{2}$, Taisen Zhuang ${ }^{3}$, \\ Shruti Wigh ${ }^{3}$, Giacomo Basadonna ${ }^{1,4}$, Barry Trink ${ }^{1,5}$, Michael Keidar ${ }^{1,5}$ and \\ Jerome Canady ${ }^{1,5, *}$ \\ 1 Jerome Canady Research Institute for Advanced Biological and Technological Sciences, Takoma Park, \\ MD 20912 USA; xcheng@usmedinnov.com (X.C.); drwrowe@usmedinnov.com (W.R.); \\ llawan@usmedinnov.com (L.L.); giacomo.basadonna@umassmed.edu (G.B.); barrytrink@gmail.com (B.T.); \\ keidar@gwu.edu (M.K.) \\ 2 School of Aeronautics and Astronautics, Purdue University, West Lafayette, IN 47907, USA; \\ ashashur@purdue.edu \\ 3 Plasma Medicine Life Sciences, Takoma Park, MD 20912, USA; tzhuang@usmedinnov.com (T.Z.); \\ swigh@usmedinnov.com (S.W.) \\ 4 Department of Surgery, University of Massachusetts School of Medicine, Worcester, MA 01655, USA \\ 5 School of Engineering and Applied Science, The George Washington University, Washington, DC 20052, USA \\ * Correspondence: drjcanady@usmedinnov.com; Tel.: +1-301-270-0147 \\ + The authors have contributed equally.
}

Received: 27 July 2018; Accepted: 10 September 2018; Published: 15 September 2018

\begin{abstract}
Triple-negative breast cancer is a phenotype of breast cancer where the expression level of estrogen, progesterone and human epidermal growth factor receptor 2 (HER2) receptors are low or absent. It is more frequently diagnosed in younger and premenopausal women, among which African and Hispanic have a higher rate. Cold atmospheric plasma has revealed its promising ant-cancer capacity over the past two decades. In this study, we report the first cold plasma jet delivered by the Canady Cold Plasma Conversion Unit and characterization of its electric and thermal parameters. The unit effectively reduced the viability of triple-negative breast cancer up to $80 \%$ without thermal damage, providing a starting point for future clinical trials.
\end{abstract}

Keywords: triple-negative breast cancer; cold atmospheric plasma; cold plasma device

\section{Introduction}

Breast cancer is the most common cancer diagnosed among US women (excluding skin cancers) and is the second leading cause of cancer death among women after lung cancer [1]. Triple-negative breast cancer refers to the breast cancer phenotype which has an absence or low level expression of estrogen, progesterone, and HER2 receptors [2]. It is known for its poor clinical outcome and lack of effective targeted therapy because women with triple-negative breast cancer do not benefit from endocrine therapy or trastuzumab. Chemotherapy is currently the mainstay of systemic medical treatment [3]. Patients with triple-negative disease have a lower three-year survival rate following chemotherapy than patients with breast cancers of other subtypes [4]. 
Cold atmospheric plasma (CAP) has been extensively studied for its biomedical use in various fields such as surface decontamination [5], wound healing [6,7], dental treatment [8], allergen destruction [9], HIV virus treatment [10] and among others [11]. In particular, the research of CAP as a potential oncotherapeutic approach has thrived over the past decade and the mechanism is been increasingly understood [12-16]. It is widely reported that CAP deactivated more than 20 types of cancer in vitro by inducing apoptosis [17-19], cell cycle arrest [20-22], endoplasmic reticulum stress [23,24] and DNA damage [25-27]. CAP has also been shown to significantly reduce tumor volume in an in vivo murine model following s phase cell cycle arrest and apoptosis [28].

With such a promising anti-cancer capacity, there is as yet to be a commercialized clinical applicable cold atmospheric plasma device reported. This study presents a new invention of an integrated cold plasma and high-frequency plasma electrosurgical system (U.S. Patent No. 9.999,462) [29] allowing tumor removal and treatment of surgical margins in a single device, and evaluates the response of triple-negative breast cancer to treatment with the device. Our study demonstrates CAP, delivered by the Canady Cold Plasma Conversion System, as a potential adjuvant for triple-negative breast cancer treatment.

\section{Materials and Methods}

\subsection{Cell Culture, Treatment, and Viability Assay}

All experiments were performed at the Jerome Canady Research Institute for Advanced Biological and Technological Sciences, in Takoma Park, MD, USA. Human breast cancer cell line MDA-MB-231 was generously donated by Professor Michael Keidar's group at The George Washington University. Cells were cultured in Dulbecco's Modified Eagle Medium (DMEM) supplemented with 10\% fetal bovine serum and $1 \%$ Pen Strep in a $37{ }^{\circ} \mathrm{C}$ and $5 \% \mathrm{CO}_{2}$ humidified incubator (Thermo Fisher Scientific, Waltham, MA, USA). When cells reached approximately $80 \%$ confluence, cells were seeded at a concentration of $10^{5}$ cells/well into 12-well plates (USA Scientific, Ocala, FL, USA) or $5 \times 10^{3}$ cells/well into 96-well plates (USA Scientific, Ocala, FL, USA). Helium flow was set to a constant $1 \mathrm{lpm}$ at power set $20 \mathrm{P}$ or $40 \mathrm{P}$ on the USMI SS-601 MCa (USMI, Takoma Park, MD, USA) or $3 \mathrm{lpm}$ and power set to $40 \mathrm{P}, 60 \mathrm{P}$, or $80 \mathrm{P}$. The plasma scalpel was placed $1.5 \mathrm{~cm}$ (at $1 \mathrm{lpm}$ ) or $2 \mathrm{~cm}$ (at $3 \mathrm{lpm}$ ) away from the surface of the cell media. Well-plates were placed on a plate heater (Benchmark, New York, NY, USA) which maintained temperature at $37^{\circ} \mathrm{C}$, providing a relatively warmer and gentle environment for the cells during treatment. Thiazolyl Blue Tetrazolium Bromide (MTT) assay was performed on the cells $48 \mathrm{~h}$ after plasma treatment following the manufacturer's protocol. All the MTT assay reagents were purchased from Sigma-Aldrich (St. Louis, MO, USA). The absorbance of the dissolved compound was measured by BioTek Synergy HTX (Winooski, VT, USA) microplate reader at $570 \mathrm{~nm}$.

\subsection{Cold Plasma Device Power and Temperature Measurement}

Electric parameters of the cold plasma discharge were measured using Tektronix P6021A (Tektronix, Beaverton, OR, USA) current probe with a frequency range of $120 \mathrm{~Hz}$ to $60 \mathrm{MHz}$ and PPE $6 \mathrm{kV}$ high voltage probe (LeCroy, Chestnut Ridge, NY, USA) attached to a digital oscilloscope Wavesurfer 3024 (LeCroy, Chestnut Ridge, NY, USA). Helium flow rates at $1 \mathrm{lpm}$ and $3 \mathrm{lpm}$ were measured at different power settings. A thermal camera (Wilsonville, OR, USA) was used to collect temperature data. The volume of the media in each well was $1 \mathrm{~mL}$ for 12-well plate and $0.1 \mathrm{~mL}$ for 96-well plate. The distance between the tip of the scalpel and the surface of the media was kept at $1.5 \mathrm{~cm}($ at $1 \mathrm{lpm})$ or $2 \mathrm{~cm}$ (at $3 \mathrm{lpm})$. Temperature measurement of the CAP-treated media was also performed with the plate heater set to $37^{\circ} \mathrm{C}$, which was consistent with cell viability experiments. The temperature of the beam and treated media was measured every minute from 0 min (immediately after the CAP was on) to $5 \mathrm{~min}$. 


\subsection{Statistics}

All viability assays were repeated for at least three times with two replicates each time. Data was plotted by Microsoft Excel 2016 (Redmond, WA, USA) as mean \pm standard error of the mean. Student $t$-test or one-way analysis of variance (ANOVA) were used to check statistical significance where applicable. Differences were considered statistically significant for ${ }^{*} p \leq 0.05$.

\section{Results}

\subsection{The Canady Cold Plasma Conversion System}

The system designed for cancer treatment in this study is reported in detail in a US patent [29]. Briefly, it is comprised of two units, namely the conversion unit (CU, USMI, Takoma Park, MD, USA) and the cold plasma probe (CPP, USMI, Takoma Park, MD, USA). The CU is integrated with a USMI SS-601 MCa, a high-frequency electrosurgical generator (ESU, USMI, Takoma Park, MD, USA) unit and converts the ESU signal. The CPP is connected to the CU output. Plasma is produced at the end of the CPP and is thermally harmless to living tissue, i.e., it is cold plasma. The connection schematics are shown in Figure 1A. The CU is equipped with three connectors, namely a gas connector (to a helium tank), an electrical connector (to ESU), and an electro-gas connector (to CPP). The CU utilizes a high voltage transformer connected to the output from the ESU. The CU up-converts voltage up to $4 \mathrm{kV}$, down-converts frequency to less than $300 \mathrm{kHz}$, and down-converts power to less than $40 \mathrm{~W}$. The CPP is connected to an electro-gas output connector of the $\mathrm{CU}$ and has a length of $0.5 \mathrm{~m}$. Figure $1 \mathrm{~B}$ shows the assembly of the whole CAP generation system.
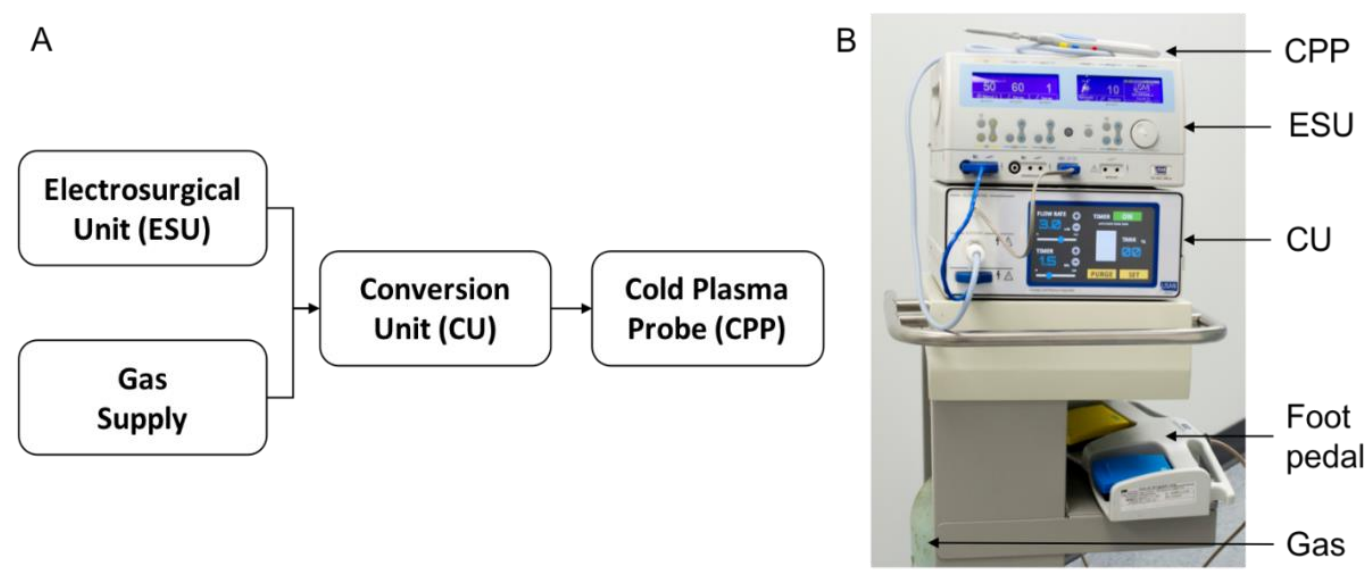

Figure 1. (A) Schematics of a system for producing cold plasma by converting a high-frequency electrosurgical unit; (B) Picture of the CAP generation system.

\subsection{Power and Temperature Measurement of CAP}

The electric parameters of the cold plasma discharge were measured and a schematic image of the setup is shown in Figure 2A. Figure 2B shows the output voltage of the ESU (orange line) and the CU (blue line). The ESU spray mode is a pulse modulated system. The ESU generated series of high voltage bursts with peak amplitude of about $1 \mathrm{kV}$ separated about $30 \mu$ s between the bursts. Each voltage burst was filled with harmonic oscillations at a frequency of about $880 \mathrm{kHz}$. The CU output waveform had a smaller resonate frequency about $140 \mathrm{kHz}$ and amplitude about 1-1.5 kV. That is to say, the $\mathrm{CU}$ is not a power generating device, but a frequency and voltage modulation device. 
A

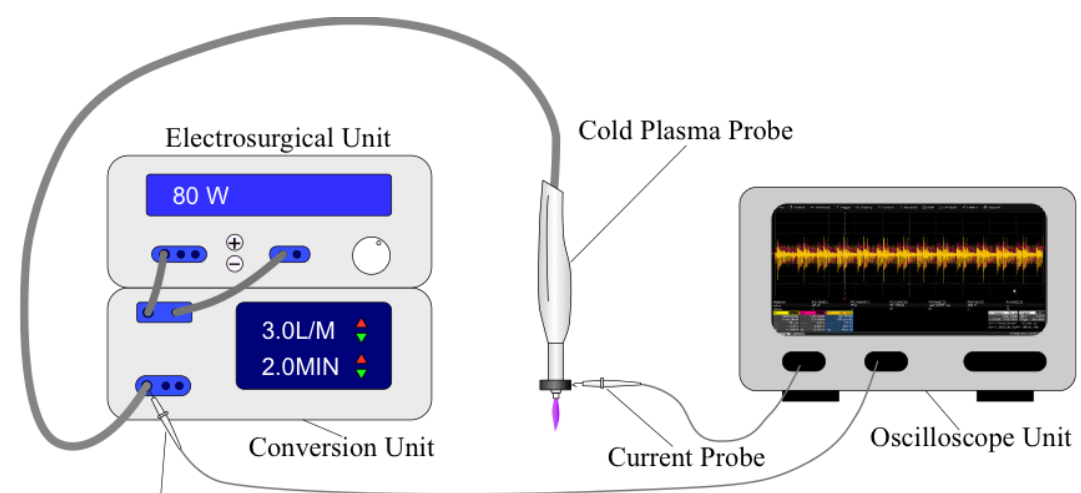

Voltage Probe

B

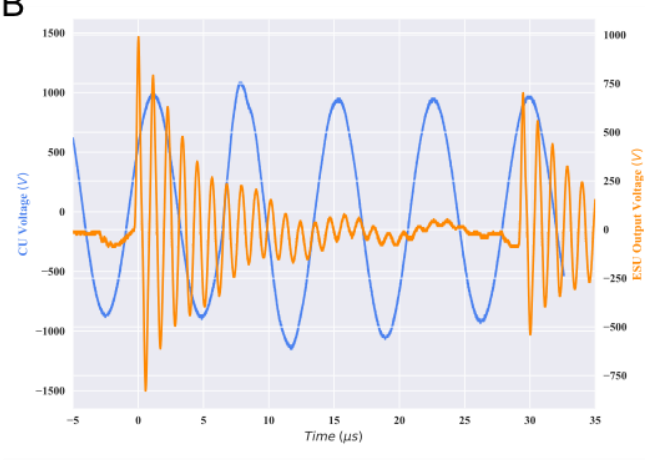

D

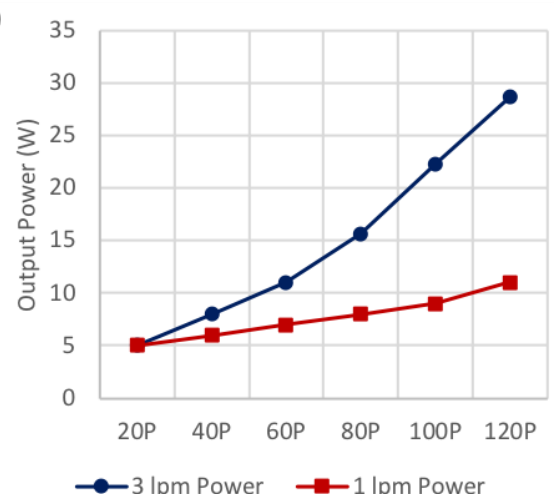

C

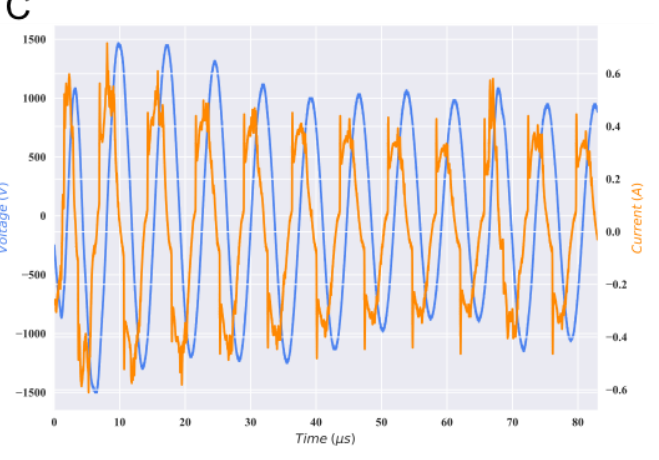

$\mathrm{E}$

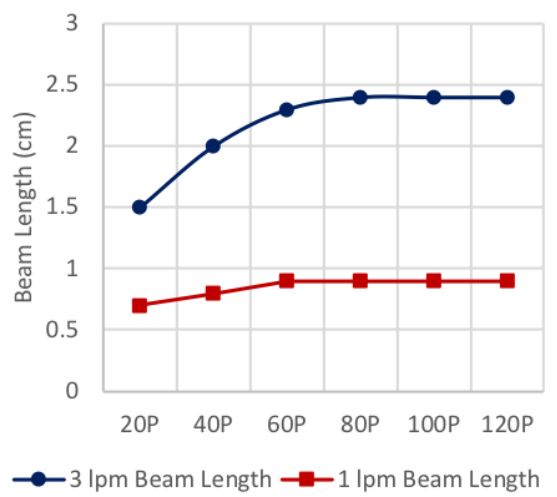

Figure 2. Output power was measured across the plasma scalpel tip. (A) Schematic image of power testing setup; (B) Output voltage of the ESU (orange line) and the CU (blue line); (C) Output voltage and current signals from the CU; (D) Power measurement of the CU; (E) Beam length of the CAP jet.

The output voltage and current signals from the CU using $3 \mathrm{lpm}$ are shown in Figure 2C. The blue line indicates the voltage output from the $\mathrm{CU}$ and the orange line is the current dissipate through the $\mathrm{CPP}$, with the ESU set to $60 \mathrm{P}$. We observed a phase shift between voltage and current curve; the current curve is about 80 degrees ahead of the voltage curve. In other words, the cold plasma system is acting as neither a pure resistive nor a pure reactive impedance. Therefore, the real power delivered to the discharge was calculated as follows. The power deposited into the cold plasma discharge was calculated by the oscilloscope directly as $\frac{1}{T} \int_{T} U \cdot I d t$ for large integration time $T=2 \mathrm{~ms}$ (over $20 \mathrm{M}$ data points, more than 200 oscillations). The power deposited into the cold plasma discharge at $20 \mathrm{P}$, $40 \mathrm{P}, 60 \mathrm{P}, 80 \mathrm{P}, 100 \mathrm{P}$, and $120 \mathrm{P}$ for $3 \mathrm{lpm}$ and $1 \mathrm{lpm}$ was plotted in Figure 2D. The power settings of $20 \mathrm{P}, 40 \mathrm{P}, 60 \mathrm{P}, 80 \mathrm{P}, 100 \mathrm{P}$, and $120 \mathrm{P}$ yield powers deposited into the cold plasma discharge of $5 \mathrm{~W}$, $8 \mathrm{~W}, 11 \mathrm{~W}, 15.7 \mathrm{~W}, 22.3 \mathrm{~W}$, and $28.7 \mathrm{~W}$ at $3 \mathrm{lpm}$ respectively; $5 \mathrm{~W}, 6 \mathrm{~W}, 7 \mathrm{~W}, 8 \mathrm{~W}, 9 \mathrm{~W}$, and $11 \mathrm{~W}$ at 1 lpm respectively. 
The length of the CAP beam was also measured at different power settings for both flow rates and plotted in Figure 2E. At $3 \mathrm{lpm}$, the length of the beam increases rapidly from 1.5 to $2 \mathrm{~cm}$ and to $2.3 \mathrm{~cm}$ when the power is increased from $20 \mathrm{P}$ to $40 \mathrm{P}$ and to $60 \mathrm{P}$. After $60 \mathrm{P}$, the length remains constant at $2.4 \mathrm{~cm}$ as the power further increases up to $120 \mathrm{P}$. This trend also applies to $1 \mathrm{lpm}$. The length of the beam increases from 0.7 to $0.8 \mathrm{~cm}$ when the power increases from $20 \mathrm{P}$ to $40 \mathrm{P}$, and maintains a length of $0.9 \mathrm{~cm}$ for $80 \mathrm{P}, 100 \mathrm{P}$, and $120 \mathrm{P}$.

Thermal images of the CAP jet with flow rates of $3 \mathrm{lpm}$ and $1 \mathrm{lpm}$ are shown in Figures 3A and $4 \mathrm{~A}$ respectively. Cell culture media was warmed up to $37^{\circ} \mathrm{C}$ beforehand and added to well plates immediately before measurement. The environment temperature was about $23{ }^{\circ} \mathrm{C}$ during the experiment. As shown in the graphs, for both flow rates the temperature of the treated media (Figures 3B and 4B) as well as the CAP beam (Figures 3C and $4 \mathrm{C}$ ) increases with power increasing from $20 \mathrm{P}$ to $120 \mathrm{P}$. The beam temperature of $3 \mathrm{lpm} \mathrm{CAP} \mathrm{is} \mathrm{about} 26$ to $30^{\circ} \mathrm{C}$, whereas the treated area of the 12 -well plate is 15 to $21^{\circ} \mathrm{C}$. In the case of $1 \mathrm{lpm}$, the beam temperature is in the range of 25.5 to $31{ }^{\circ} \mathrm{C}$, and the treatment area is roughly 23 to $36{ }^{\circ} \mathrm{C}$.
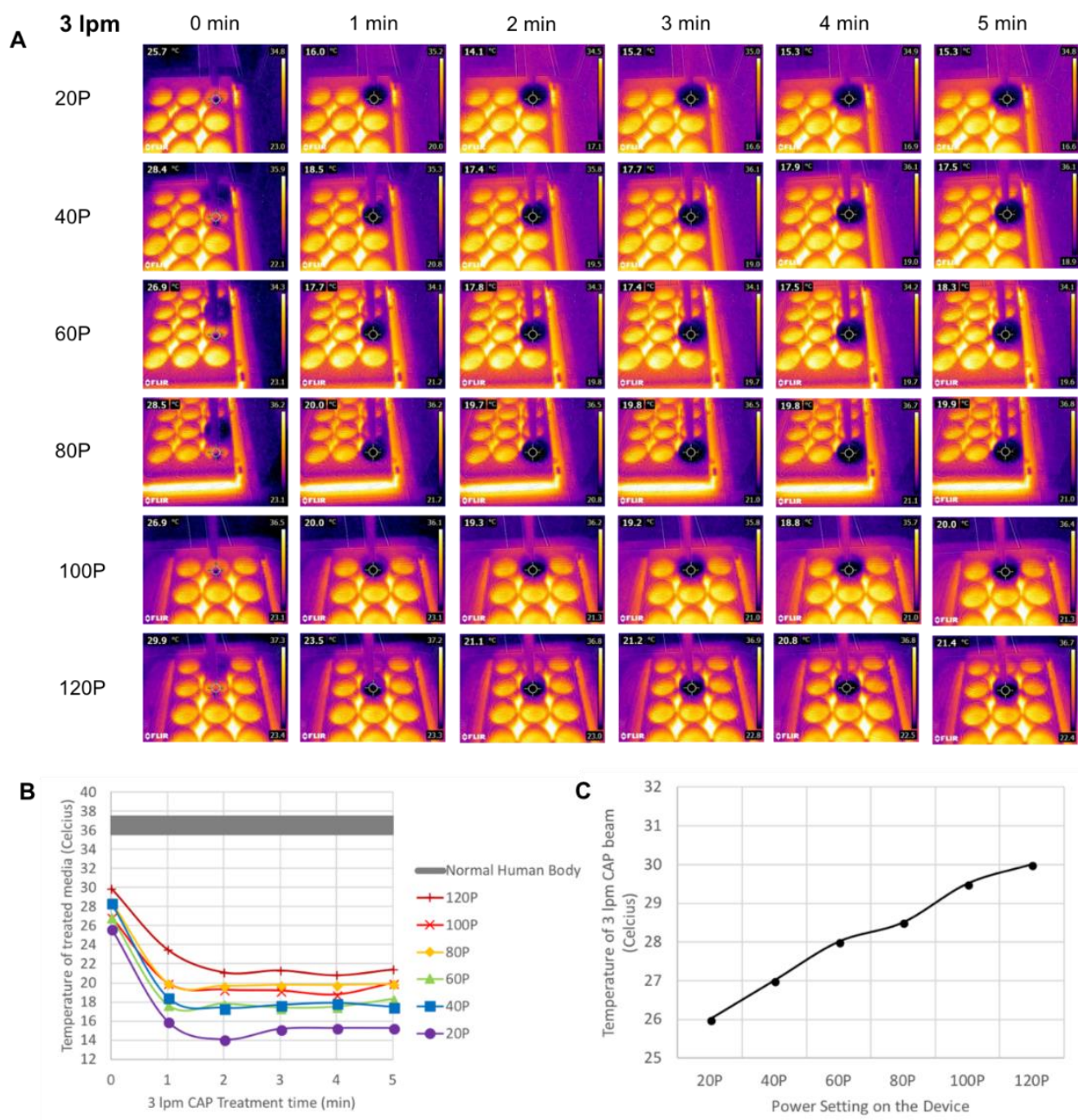

Figure 3. Temperature measurement at flow rate of $3 \mathrm{lpm}$ for each power setting (A) Thermal images of CAP-treated media; (B) Temperature of CAP-treated media as a function of treatment time; (C) Temperature of the CAP beam. 

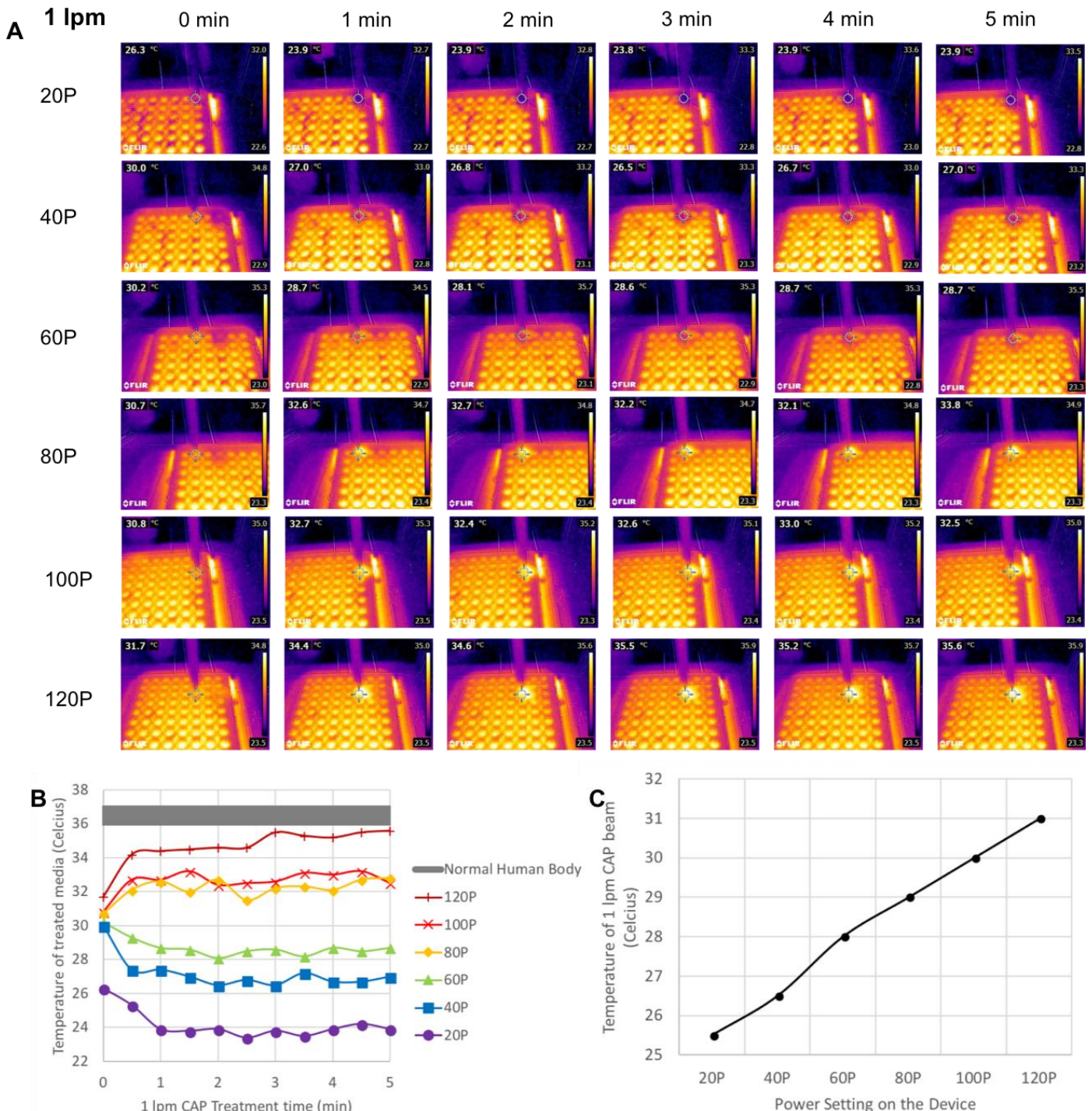

Figure 4. Temperature measurement at flow rate of $1 \mathrm{lpm}$ for each power setting (A) Thermal images of CAP-treated media; (B) Temperature of CAP-treated media as a function of treatment time; (C) Temperature of the CAP beam.

\subsection{Cell Viability after CAP Treatment}

Cells were treated by the Canady Cold Plasma Conversion System and viability was quantified by MTT assay $48 \mathrm{~h}$ after CAP treatment. As shown in Figure 5A,B primary axis, $\mathrm{CAP}$ treatment significantly reduced the proliferation of triple-negative cancer cells at various conditions. CAP treatment of MDA-MB-231 significantly reduces viability at nearly all doses tested using $3 \mathrm{lpm}$ (Figure 5A). At $1 \mathrm{lpm}$ flow rate, 90 to $120 \mathrm{~s}$ of CAP treatment was needed to significantly reduce viability (Figure $5 \mathrm{~B}$ ).

The energy delivered by the CU to the CPP can be calculated as

$$
E=P \times t
$$

where $E$ is the total energy of the CAP (J) delivered by the system; $P$ is the power measured at the end of the CPP (W), and $t$ is the treatment time (s). The consumed energy of each CAP treatment condition used in this study was plotted as the secondary axis of Figure 5A (3 lpm) and 5B (1 lpm). The reduction 
of cell viability matches the energy consumption for both flow rates and this trend is consistent across all power and time settings tested. A picture of the cells treated by the CPP is shown in Figure 5C.
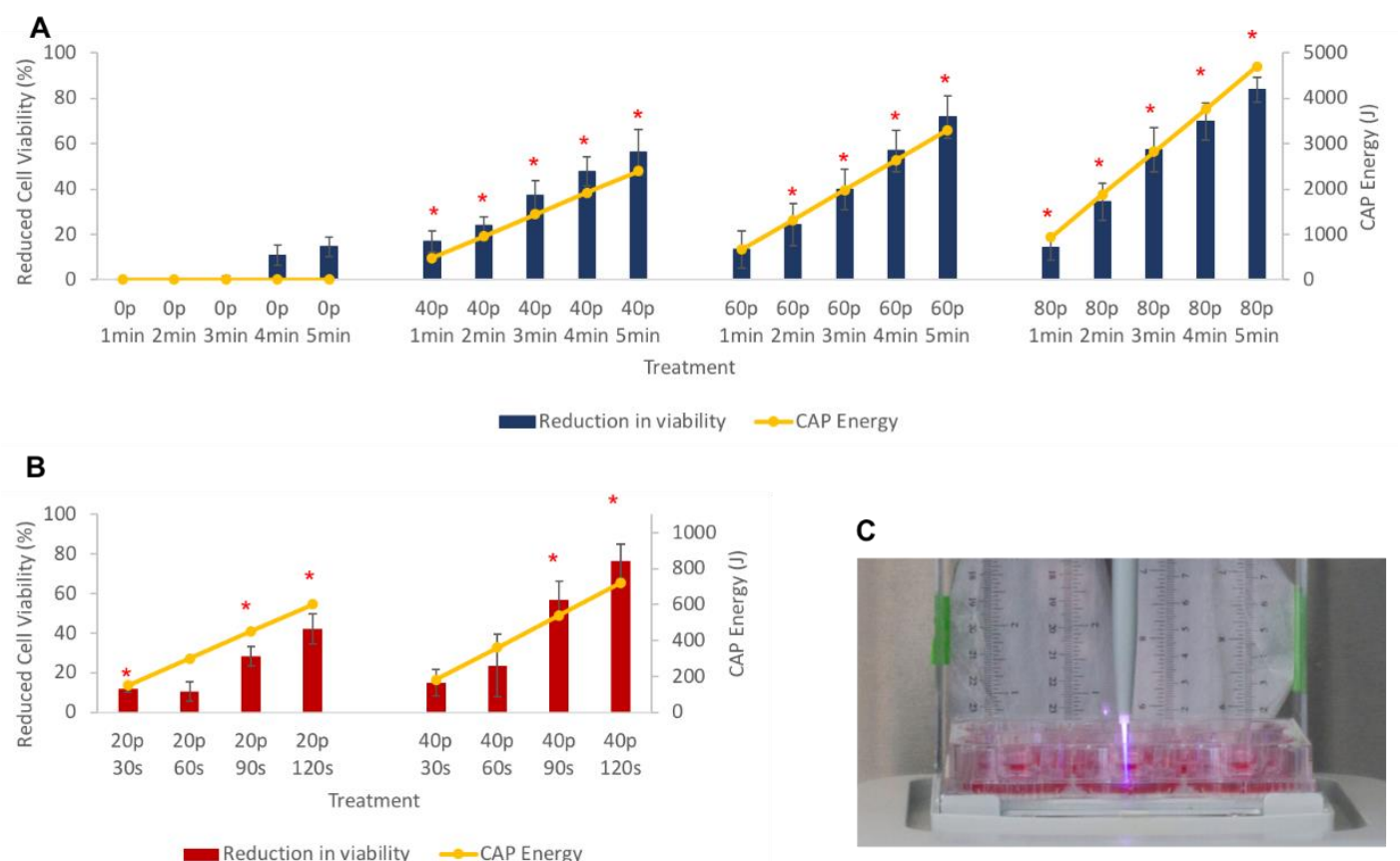

Figure 5. Reduced viability of treatment on MDA-MB-231 measured by MTT assay (bar chart, primary axis) and energy deposited in the corresponding CAP treatment (line chart, secondary axis) (A) Cells were treated by CAP at $3 \mathrm{lpm}$ in 12-well plates; (B) Cells were treated by CAP at $1 \mathrm{lpm}$ in 96-well plates; (C) Picture of $3 \mathrm{lpm}$ CAP jet treating the cells in a 12-well plate. ${ }^{*} \mathrm{P} \leq 0.05$.

\section{Discussion}

Cold plasma can be generated in various forms including dielectric barrier discharge, corona discharge, and plasma jets [30]. The Canady Cold Plasma Conversion Unit reported in this study is the first cold plasma device that utilizes a high voltage transformer to up-convert the voltage, down-convert the frequency, and down-convert the power of the high voltage output from an electrosurgical unit (U.S. Patent No. 9.999,462) [29].

The plasma jet generated by the Canady Cold Plasma Conversion System is indeed "cold". The beam temperature for all conditions tested is within the range of 26 to $31^{\circ} \mathrm{C}$. It has a cooling effect on the treated media when the flow rate is high and/or power is low. With a flow rate at $3 \mathrm{lpm}$, the beam temperature is 26 to $30^{\circ} \mathrm{C}$ for $20 \mathrm{P}$ to $120 \mathrm{P}$, whereas the treated media in the 12 -well plate is about 15 to $21^{\circ} \mathrm{C}$ respectively.

The beam temperature of $1 \mathrm{lpm}$ CAP is 25.5 to $31^{\circ} \mathrm{C}$ for $20 \mathrm{P}$ to $120 \mathrm{P}$, which is very close to that of $3 \mathrm{lpm}$. Although the power parameters of CAP are higher at $3 \mathrm{lpm}$ than $1 \mathrm{lpm}$, as shown above in the Results Section, the similar temperature could be resulted from better heat convection of the higher flow. For a lower power setting of $20 \mathrm{P}$ to $60 \mathrm{P}$, the temperature of the CAP-treated media in the 96-well plate at $1 \mathrm{lpm}, 24$ to $29^{\circ} \mathrm{C}$, is lower or close to the CAP beam temperature. However, for the higher power setting of $80 \mathrm{P}$ to $120 \mathrm{P}$, the temperature of the treated media in the 96-well plate, 32 to $36{ }^{\circ} \mathrm{C}$, is 3 to 5 degrees higher than the beam temperature. Theoretically, the media temperature should only increase to the beam temperature based on the principle of heat transfer. However, during the experiments we observed that the CAP jet was intensified, which could be caused by the energy dissipating to the wall of the 96-well plate due to the high power as well as the turbulence resulting from a small well size. The increased intensity of the CAP jet is demonstrated as high brightness in the thermal images in Figure 4A Row 4 to Row 6 ( $80 \mathrm{P}$ to $120 \mathrm{P}$ ). The length of the CAP beam also presents 
evidence of increased intensity. As shown above in Figure 2C, the beam is only $0.9 \mathrm{~cm}$ at $80 \mathrm{P}$ to $120 \mathrm{P}$ for $1 \mathrm{lpm}$ when measured in open air, while the thermal images in Figure 4A were captured with $1.5 \mathrm{~cm}$ gap distance between the CPP tip and the media. This disparity is because when treating in the well, even at lower power settings, the beam is able to reach $1.5 \mathrm{~cm}$ and contact the media. The $3 \mathrm{lpm}$ CAP jet does not present this issue because the diameter of a 12-well plate is significantly larger than the CAP jet.

When applied to cells, power settings of $20 \mathrm{P}$ to $80 \mathrm{P}$ for $3 \mathrm{lpm}$ and $20 \mathrm{P}$ to $40 \mathrm{P}$ for $1 \mathrm{lpm}$ were chosen to ensure the integrity of the CAP delivered to the cells. The temperature of the treatment area is between 15 to $30{ }^{\circ} \mathrm{C}$ for all treatment conditions at all times, suggesting no thermal damage to the cells.

The CAP generated by the Canady Cold Plasma Conversion System affects triple-negative breast cancer in a power- and time-dependent manner which corresponds with the increased output power and beam length shown in Figure $2 \mathrm{C}$. The CAP reduced the viability of triple-negative breast cancer up to $80 \%$ at the highest power for both flow rates. To further illustrate the correspondence between cell viability and CAP power and treatment time, we calculate the energy delivered by the system; E. The close correlation between energy consumption and reduction in viability may be important for comparing results between different CAP devices. Difference cell types may also respond differently to CAP treatment, therefore more studies have been performed to confirm the efficacy of the CAP system on other solid tumor cancer cell lines [31] as well as the safety of the unit on normal tissue [32]. Future animal studies are needed to determine the optimal dosage for cancer elimination while remaining safe for normal tissue.

Although at $3 \mathrm{lpm}$, the CAP jet delivers higher energy than $1 \mathrm{lpm}$ with the same power and time setting, the MTT assay shows a similar reduction in viability (Figure 5A,B). Thus, direct comparison of the cell viability cannot be made between $3 \mathrm{lpm}$ and $1 \mathrm{lpm}$ despite the same power setting and treatment time due to different beam length, well size, medium volume, and cell number between the two conditions. This was also reported repeatedly by other researchers worldwide $[33,34]$. This study intends to focus on the introduction of the Canady Cold Plasma Conversion System and its efficacy on the treatment of triple-negative breast cancer for both flowrates.

To better understand the strength of each cold plasma dosage and evaluate the efficiency of the cold plasma beam during treatment, cell viability reduction rate (CVRR) was introduced in this paper. CVRR was calculated based on the cell viability rate versus the time at a constant ESU power setting (\%/s). Figure 6 shows the CVRR values and averaged CVRR corresponding to $40 \mathrm{P}, 60 \mathrm{P}$ and $80 \mathrm{P}$ ESU power setting at $3 \mathrm{lpm}$. There is little difference when comparing the CVRR between treatment times and the average only increases slightly with increased power. In other words, the average CVRR value could represent the overall performance of the CAP for that power setting. More importantly, one could establish a treatment projected solution based on the average CVRR value, and in that sense, CVRR is an ideal parameter to calculate the CAP dose.

The poor prognosis and low overall survival rate of triple-negative breast cancer demands a novel and safe treatment. The high-frequency converted cold plasma system integrates coagulation and CAP in a single device, making it more practical for medical applications. After the surgeon removes the cancerous tumor, CAP is subsequently sprayed at the surgical margins to ablate any remaining cancerous tissue or cells, thus reducing the chances of cancer recurrence. CAP treatment acts as an important adjunct to the current treatment protocol for solid cancerous tumors. This new plasma system will change the landscape of electrosurgery and cancer therapy as well as offer cancer patients new hope in the very near-future. 


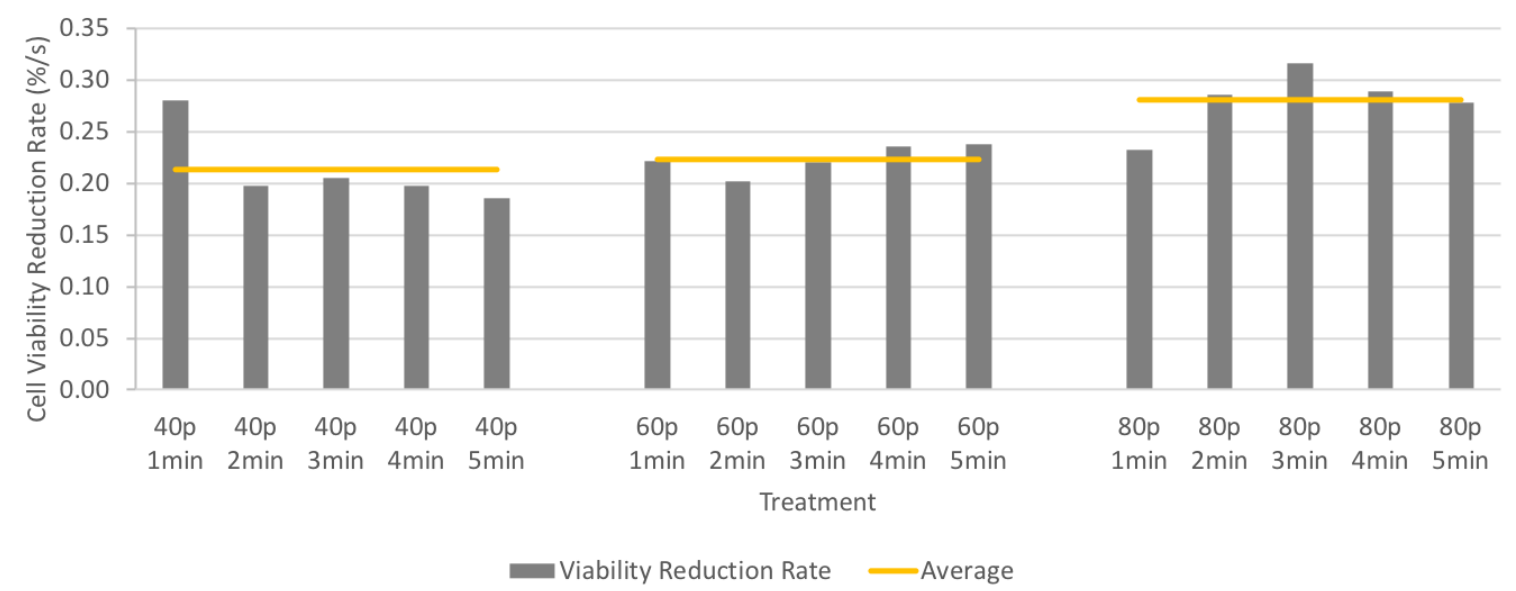

Figure 6. Reduction rate of MDA-MB-231 cells by CAP treatment under different conditions.

\section{Conclusions}

This study reports the first cold plasma jet delivered by the Canady Cold Plasma Conversion Unit, which was characterized and tested on triple-negative breast cancer cells. Viability of these cells was effectively reduced in a time- and power-dependent manner. Our CAP device, a direct conversion from a high-frequency electrosurgical unit, allows for the removal of a tumor and the following treatment by CAP for ablating cancer cells using a single device, and this study will contribute to the dosage estimation for patients in future clinical applications.

Author Contributions: Conceptualization, X.C., W.R., G.B., B.T., M.K. and J.C.; Data curation, X.C., W.R., L.L. and T.Z.; Formal analysis, X.C., W.R. and T.Z.; Funding acquisition, J.C.; Investigation, X.C., W.R., L.L., T.Z. and S.W.; Methodology, X.C., W.R., A.S. and M.K.; Project administration, X.C. and W.R.; Software, X.C., W.R. and T.Z.; Supervision, M.K. and J.C.; Validation, X.C. and W.R.; Writing-original draft, X.C., W.R. and T.Z.; Writing-review \& editing, X.C., W.R., A.S., T.Z., G.B., B.T., M.K. and J.C.

Funding: This research received no external funding.

Acknowledgments: The authors would like to thank the engineer team at Plasma Medicine Life Sciences for technical support of the plasma unit. This research was funded by US Medical Innovations, LLC.

Conflicts of Interest: The authors declare no conflict of interest.

\section{References}

1. DeSantis, C.E.; Ma, J.; Goding Sauer, A.; Newman, L.A.; Jemal, A. Breast cancer statistics, 2017, racial disparity in mortality by state. CA-Cancer J. Clin. 2017, 67, 439-448. [CrossRef] [PubMed]

2. Wahba, H.A.; El-Hadaad, H.A. Current approaches in treatment of triple-negative breast cancer. Cancer Biol. Med. 2015, 12, 106-116. [PubMed]

3. Foulkes, W.D.; Smith, I.E.; Reis-Filho, J.S. Triple-negative breast cancer. New Engl. J. Med. 2010, 363, 1938-1948. [CrossRef] [PubMed]

4. Liedtke, C.; Mazouni, C.; Hess, K.R.; Andre, F.; Tordai, A.; Mejia, J.A.; Symmans, W.F.; Gonzalez-Angulo, A.M.; Hennessy, B.; Green, M.; et al. Response to neoadjuvant therapy and long-term survival in patients with triple-negative breast cancer. J. Clin. Oncol. 2008, 26, 1275-1281. [CrossRef] [PubMed]

5. Niemira, B.A.; Boyd, G.; Sites, J. Cold plasma rapid decontamination of food contact surfaces contaminated with salmonella biofilms. J. Food Sci. 2014, 79, M917-M922. [CrossRef] [PubMed]

6. Schmidt, A.; Woedtke, T.V.; Stenzel, J.; Lindner, T.; Polei, S.; Vollmar, B.; Bekeschus, S. One year follow-up risk assessment in skh-1 mice and wounds treated with an argon plasma jet. Int. J. Mol. Sci. 2017, 18, 868. [CrossRef] [PubMed] 
7. Schmidt, A.; Wende, K.; Bekeschus, S.; Bundscherer, L.; Barton, A.; Ottmuller, K.; Weltmann, K.D.; Masur, K. Non-thermal plasma treatment is associated with changes in transcriptome of human epithelial skin cells. Free Radical Res. 2013, 47, 577-592. [CrossRef] [PubMed]

8. Pierdzioch, P.; Hartwig, S.; Herbst, S.R.; Raguse, J.D.; Dommisch, H.; Abu-Sirhan, S.; Wirtz, H.C.; Hertel, M.; Paris, S.; Preissner, S. Cold plasma: A novel approach to treat infected dentin-a combined ex vivo and in vitro study. Clin. Oral Investig. 2016, 20, 2429-2435. [CrossRef] [PubMed]

9. Wu, Y.; Liang, Y.; Wei, K.; Li, W.; Yao, M.; Zhang, J. Rapid allergen inactivation using atmospheric pressure cold plasma. Environ. Sci. Technol. 2014, 48, 2901-2909. [CrossRef] [PubMed]

10. Volotskova, O.; Dubrovsky, L.; Keidar, M.; Bukrinsky, M. Cold atmospheric plasma inhibits hiv-1 replication in macrophages by targeting both the virus and the cells. PLoS ONE 2016. [CrossRef] [PubMed]

11. Bußler, S.; Herppich, W.B.; Neugart, S.; Schreiner, M.; Ehlbeck, J.; Rohn, S.; Schlüter, O. Impact of cold atmospheric pressure plasma on physiology and flavonol glycoside profile of peas (pisum sativum “Salamanca”). Food Res. Int. 2015, 76, 132-141. [CrossRef]

12. Yan, D.; Sherman, J.H.; Keidar, M. Cold atmospheric plasma, a novel promising anti-cancer treatment modality. Oncotarget 2017, 8, 15977-15995. [CrossRef] [PubMed]

13. Keidar, M. Plasma for cancer treatment. Plasma Sources Sci. Technol. 2015, 24, 20. [CrossRef]

14. Laroussi, M.; Lu, X.; Keidar, M. Perspective: The physics, diagnostics, and applications of atmospheric pressure low temperature plasma sources used in plasma medicine. J. Appl. Phys. 2017. [CrossRef]

15. Schlegel, J.; Köritzer, J.; Boxhammer, V. Plasma in cancer treatment. Clin. Plasma Med. 2013, 1, 2-7. [CrossRef]

16. Tanaka, H.; Ishikawa, K.; Mizuno, M.; Toyokuni, S.; Kajiyama, H.; Kikkawa, F.; Metelmann, H.; Hori, M. State of the art in medical applications using non-thermal atmospheric pressure plasma. Rev. Mod. Plasma Phys. 2017, 1, 89. [CrossRef]

17. Ishaq, M.; Han, Z.J.; Kumar, S.; Evans, M.D.M.; Ostrikov, K.K. Atmospheric-pressure plasma- and trail-induced apoptosis in trail-resistant colorectal cancer cells. Plasma Processes Polym. 2015, 12, 574-582. [CrossRef]

18. Adachi, T.; Tanaka, H.; Nonomura, S.; Hara, H.; Kondo, S.; Hori, M. Plasma-activated medium induces a549 cell injury via a spiral apoptotic cascade involving the mitochondrial-nuclear network. Free Radical Biol. Med. 2015, 79, 28-44. [CrossRef] [PubMed]

19. Weiss, M.; Gumbel, D.; Hanschmann, E.M.; Mandelkow, R.; Gelbrich, N.; Zimmermann, U.; Walther, R.; Ekkernkamp, A.; Sckell, A.; Kramer, A.; et al. Cold atmospheric plasma treatment induces anti-proliferative effects in prostate cancer cells by redox and apoptotic signaling pathways. PLoS ONE 2015. [CrossRef] [PubMed]

20. Shi, X.; Zhang, G.; Chang, Z.; Wu, X.; Liao, W.; Li, N. Viability reduction of melanoma cells by plasma jet via inducing G1/S and G2/M cell cycle arrest and cell apoptosis. IEEE Trans. Plasma Sci. 2014, 42, 1640-1647. [CrossRef]

21. Gherardi, M.; Turrini, E.; Laurita, R.; De Gianni, E.; Ferruzzi, L.; Liguori, A.; Stancampiano, A.; Colombo, V.; Fimognari, C. Atmospheric non-equilibrium plasma promotes cell death and cell-cycle arrest in a lymphoma cell line. Plasma Processes Polym. 2015, 12, 1354-1363. [CrossRef]

22. Volotskova, O.; Hawley, T.S.; Stepp, M.A.; Keidar, M. Targeting the cancer cell cycle by cold atmospheric plasma. Sci. Rep. 2012. [CrossRef] [PubMed]

23. Ruwan Kumara, M.H.; Piao, M.J.; Kang, K.A.; Ryu, Y.S.; Park, J.E.; Shilnikova, K.; Jo, J.O.; Mok, Y.S.; Shin, J.H.; Park, Y.; et al. Non-thermal gas plasma-induced endoplasmic reticulum stress mediates apoptosis in human colon cancer cells. Oncol. Rep. 2016, 36, 2268-2274. [CrossRef] [PubMed]

24. Zhao, S.; Xiong, Z.; Mao, X.; Meng, D.; Lei, Q.; Li, Y.; Deng, P.; Chen, M.; Tu, M.; Lu, X.; et al. Atmospheric pressure room temperature plasma jets facilitate oxidative and nitrative stress and lead to endoplasmic reticulum stress dependent apoptosis in HepG2 cells. PLoS ONE 2013. [CrossRef] [PubMed]

25. Zhang, X.; Zhang, C.; Zhou, Q.Q.; Zhang, X.F.; Wang, L.Y.; Chang, H.B.; Li, H.P.; Oda, Y.; Xing, X.H. Quantitative evaluation of DNA damage and mutation rate by atmospheric and room-temperature plasma (ARTP) and conventional mutagenesis. Appl. Microbiol. Biotechnol. 2015, 99, 5639-5646. [CrossRef] [PubMed]

26. Chung, W.H. Mechanisms of a novel anticancer therapeutic strategy involving atmospheric pressure plasma-mediated apoptosis and DNA strand break formation. Arch. Pharmacal Res. 2016, 39, 1-9. [CrossRef] [PubMed] 
27. Chang, J.W.; Kang, S.U.; Shin, Y.S.; Kim, K.I.; Seo, S.J.; Yang, S.S.; Lee, J.S.; Moon, E.; Baek, S.J.; Lee, K.; et al. Non-thermal atmospheric pressure plasma induces apoptosis in oral cavity squamous cell carcinoma: Involvement of DNA-damage-triggering sub-G1 arrest via the ATM/p53 pathway. Arch. Biochem. Biophys. 2014, 545, 133-140. [CrossRef] [PubMed]

28. Vandamme, M.; Robert, E.; Lerondel, S.; Sarron, V.; Ries, D.; Dozias, S.; Sobilo, J.; Gosset, D.; Kieda, C.; Legrain, B.; et al. Ros implication in a new antitumor strategy based on non-thermal plasma. Int. J. Cancer 2012, 130, 2185-2194. [CrossRef] [PubMed]

29. Canady, J.; Shashurin, A.; Keidar, M.; Zhuang, T. Integrated cold plasma and high frequency plasma electrosurgical system and method. U.S. Patent 9,999,462, 19 June 2018.

30. Weltmann, K.D.; Kindel, E.; von Woedtke, T.; Hähnel, M.; Stieber, M.; Brandenburg, R. Atmospheric-pressure plasma sources: Prospective tools for plasma medicine. Pure Appl. Chem. 2010, 82, 1223-1237. [CrossRef]

31. Rowe, W.; Cheng, X.; Ly, L.; Zhuang, T.; Basadonna, G.; Trink, B.; Keidar, M.; Canady, J. The canady helios cold plasma scalpel significantly decreases viability in malignant solid tumor cells in a dose-dependent manner. Plasma 2018, 1, 177-188. [CrossRef]

32. Ly, L.; Jones, S.; Shashurin, A.; Zhuang, T.; Rowe, W.; Cheng, X.; Wigh, S.; Naab, T.; Keidar, M.; Canady, J. A new cold plasma jet: Performance evaluation of cold plasma, hybrid plasma and argon plasma coagulation. Plasma 2018, 1, 189-200. [CrossRef]

33. Yan, D.; Talbot, A.; Nourmohammadi, N.; Cheng, X.; Canady, J.; Sherman, J.; Keidar, M. Principles of using cold atmospheric plasma stimulated media for cancer treatment. Sci. Rep. 2015. [CrossRef] [PubMed]

34. Xu, X.; Dai, X.; Xiang, L.; Cai, D.; Xiao, S.; Ostrikov, K. Quantitative assessment of cold atmospheric plasma anti-cancer efficacy in triple-negative breast cancers. Plasma Processes Polym. 2018. [CrossRef]

(C) 2018 by the authors. Licensee MDPI, Basel, Switzerland. This article is an open access article distributed under the terms and conditions of the Creative Commons Attribution (CC BY) license (http:/ / creativecommons.org/licenses/by/4.0/). 